\title{
ETHICAL LEADERSHIP AND STAFF INNOVATIVE BEHAVIOUR IN NIGERIA
}

Abdullahi, Nimota Jibola Kadir ${ }^{*}$

\begin{abstract}
This study investigated ethical leadership and staff innovative behaviour in Nigeria. The aims of this study are to find out the relationships that exist among ethical leadership and staff innovative behaviour. This study also seeks to find the level of practice for the parts in ethical leadership and staff innovative. Quantitative research design was adopted in the study. Sample of 350 participants were randomly selected from the sample university in line with Research Advisor (2006), table of determining sample size of known population. Pearson correlations and linear regression analysis were used to analyze the collected data. The findings show that leadership integrity, power sharing and fairness positively and significantly correlated with staff innovative behaviour. The result also shows that staff innovative behaviour can be influenced by ethics behaviour of academic leaders. In order to improve staff innovative behaviour and development of universities, academic leaders must demonstrate high standards of professional conduct, encourage an open and transparent culture, develop framework that will encourage staff to work together irrespective of their race, gender, religion or age, as well as demonstrate effective fairness in terms of unbiased evaluation of staff performance. If all these are put in place, staff innovative behaviour (self-efficacy, knowledge sharing, and idea generation) will be achieved.
\end{abstract}

Keywords: Leadership integrity; power sharing; fairness; staff innovative behaviour; university; Nigeria

\section{Introduction}

Ethical leadership is an important factor which is anticipated to have an impact on the staff innovative behaviour. It has become a laudable phenomenon of effectiveness in Nigeria universities due to ethical scandals that may hinder the organizational efficiency. The recent scandals of corruption, sexual harassment, and unethical conduct prevail in dealing with staff and students. Unethical leader is the one who fails to follow rules, take responsibility, and perform appropriately in discharging duties.

The behaviour of an organizational leader plays a vital role in achieving staff innovative behaviour toward the achievement of stated goals and objectives. Ethical leaders are

This work is Licensed under a Creative Commons Attribution-Non-Commercial 4.0 International License (c) (i) (8)

* Abdullahi, Nimota Jibola Kadir, Ph.D. Department of Education Management, Faculty of Education. University of Ilorin, Nigeria 
those who create an enabling working or learning environment through the exchange of idea, integrity, fairness, role clarification, concern for sustainability, respect employees' right as well as ethical guidance ${ }^{1}$. The effective management skills of the leader may play a crucial role in bringing positive working environment that will enhance the quality of work done as it will improve staff innovative behaviour. Innovation can be seen as a way of creating useful ideas or solutions to solve problem under study. Innovation starts with recognition and creation of ideas that challenge organizations' past practices and operating principles. University education is essential in the development of a nation because it produces the higher manpower needed by the nation to drive the economy and govern the people. ${ }^{1}$

University education is viewed as the center in the pursuits of socio-economic development of a nation by channeling its human capital to become productive citizens $^{2 \& 3}$. The innovative behaviour of university lecturers help the university education sector cope with the changing society and enhance their self-efficacy, knowledge sharing, idea generation as well as human capacity in teaching, research, and community development ${ }^{4}$. Currently, universities in the world are surrounded by competitors in term of ranking, thus, it is necessary that universities harness the innovative behaviour of staff as a weapon for achieving its goals.

Numerous studies have been carried out in the area of ethical leadership and workers innovative behaviour $\mathrm{Heba}^{5}$. investigated impact of ethical leadership and employee creativity. Taqveem and $\mathrm{Ajimal}^{6}$ investigated influence of ethical leadership and employees innovative work behaviour:

Examination of individual level psychological mediation. Shamia and Andi ${ }^{7}$ conducted ethical leadership and employee welfare on the facilitating part of physical empowerment. Agha et.al. ${ }^{8}$ examined the influence of ethical leadership and staff commitment in Nigeria. Peter ${ }^{9}$ carried out ethical leadership and performance of workers

${ }^{1}$ Oates, V. \& Delmau, T. Ethical Leadership: A Legacy for Longer Future. Journal of Performance, 5(2), (2013), 20-27.

${ }^{2}$ Khan, M. F. U. Role of Performance Appraisal System on Employee Motivation. Journal of Business Management, 8(1), (2011), 60-83.

${ }^{3}$ Adeyemi, T. O. Human resources in education. J. B Babalola \& A. O. Ayeni (Eds.), Educational management theories and tasks. (Lagos: Macmillan Publishers Limited, 2009).

${ }^{4}$ Onyeizugbe, C. U., Obiageli, L. O. \& Igbodo, R. O. Tertiary Education Trust Fund International Programmes and Academic Staff Development of Selected Universities in South East, Nigeria. Journal of Economics and Public Finance, 2(1), (2016), 171-193.

${ }^{5}$ Heba, K. E. Influence of Ethical Leadership on Workers Creativity. International Journal of Economics and management Sciences, 7(5), (2018), 1-13.

${ }^{6}$ Taqveen, T. Z. \& Ajimal, W. Influence of Ethical Leadership on Innovative Work Behaviour: Examination of Individual Level of Psychological Mediators. Pakistan Journal of Commerce and Social Sciences, 11(2), (2017), 448-470.

${ }^{7}$ Shamia, D. R. \& Andi, I. Y. Influence of Ethical Leadership on Employee Well-Being: The Mediating Role of Psychological Empowerment. Journal of Indonesian Economy and Business, 32(2), (2017), 121-137.

${ }^{8}$ Agha, N. C., Nwekpa, K. C. \& Eze, O. R. Impact of Ethical Leadership on Employee Commitment in Nigeria: A Study of Innoson Technical and Industrial Company Limited, Enugu. International Journal of Development and management, 12(1), (2017), 202-214.

${ }^{9}$ Peter, O. O. Ethical Leadership on Employee Performance in Uganda. Net Journal of Business Management, 3(1), (2015), 1-12. 
in Uganda. Sample of 160 employees was used for data collection. A designed questionnaire was used for data gathering and analyzed using Pearson correlation coefficient and regression analysis to determine correlation between ethical leadership and workers performance. The finding shows that employee performance has significantly influenced by ethical behaviour. Although the effect of different forms of leadership on innovative work behaviour has been understudy in past. However, there is little if any or none about the ethical leadership and management of staff innovative behaviour in Nigeria University. Also, to the researchers' knowledge, there have been no researches in Nigeria so far that look at integrity, power sharing, and fairness as critical variables to be used by academic leaders in improving staff innovative behaviour. Therefore, this study endeavour to fill the gaps left by previous scholars.

The following objectives have been formulated to achieve the aims:

1) Determine the level of ethical leadership practice as perceived by staff in university of Ilorin, Nigeria.

2) To measure the level of staff innovative behaviour in the university of Ilorin, Nigeria.

3) To identify effect of ethical leadership practice on staff innovative behaviour in university of Ilorin, Nigeria.

\section{Literature Review}

\section{Ethical leadership}

Leadership generally means a process by which a person influences others to accomplish a task in order to realize predetermined goals. Leadership is a process of influencing a group of individuals in a work environment to achieve a common goal ${ }^{10}$. Brown et.al. ${ }^{11}$ view ethical leadership as a way of promoting ethical standards in terms of integrity, fairness as well as ensuring power sharing in dealing with staff with the aim of achieving organizational goals. Ethical leaders refer to individual who are objective and unbiased, considering the people's wishes and opinions as well as protecting their employees' right $^{12}$.

Ciulla ${ }^{13}$ viewed ethical leadership as a way of leading others with an altruistic motive, respecting the dignity and right of people in order to motivate followers to participate in ethical behaviours. Ethical leader is a leader who behaves positively for the benefit of the followers ${ }^{14}$. Leaders are the key determinant of realizing the stated organisational

\footnotetext{
${ }^{10}$ Northhouse, P. G. Leadership Theory and Practice. Thousand Oaks, (CA: Sage, 2010)

${ }^{11}$ Brown, M. E., Trevino, L. K. \& Harrison, D. Ethical Leadership: A Social Learning Perspective for Construct Development and Testing. Journal of Organisational Behaviour and Human Decision Process, 97, (2005), 117-134.

${ }^{12}$ Zhu., W., May, D. R. \& Avolio, B J. The Impact of Ethical Leadership Behaviour on Employee Outcome: The Role of Psychological Empowerment and Authenticity. Journal of Leadership and Organizational Studies, 11, (2004), 16-20

${ }^{13}$ Ciulla, J. B. Ethics: The Heart Of Leadership. (2 ${ }^{\text {nd }}$ ed.), (USA: Quorum Books, 2014)

${ }^{14}$ Toor, S. \& Ofori, G. Ethical Leadership: Examining the Relationship with Full Range Leadership Model, Employee Outcome and Organizational Culture. Journal of Business Ethics, 90, (2009), 533-547.
} 
objective and establishing the pace for staff innovative behaviour in terms of selfefficacy, knowledge sharing, and idea generation ${ }^{15}$. Ethical leadership in this study refers to the integrity, power sharing, and fairness of leader in motivating staff towards achieving the best of their behaviour so as to realize the organizational objectives.

Leaders that have integrity build trust in their relationship with followers. The extent of which staff involves in innovative behaviour could be influenced by personality factors of leaders in the areas of transparency, loyalty, equality, and fairness, rather than being self-centered in achieving personal goals. Leader with high integrity are more probable to share power with the led.

Power sharing leadership can be seen as a leader who engages employees in leadership through delegation of authority, participative decision-making and share responsibility for the attainment of goals and objectives.

Power sharing according to Carson et.al. ${ }^{16}$ is a process of distributing leadership influence across multiple team members. This means power sharing as the process of information sharing, improve creation of new ideas and innovation. Power sharing is also regarded as ethical conduct of moral leader to delegate authority and inspire the subordinates to contribute in decision-making of an organization ${ }^{17}$.

\section{Staff innovative behaviour}

Staff innovative behaviour has been defined as an intrinsic behaviour of an individual to introduce or generate ideas towards the development of an organization ${ }^{18}$. It is a way of generating new techniques, suggesting new ways of performing task, facilitating the implementation of generating ideas to achieve stated objectives ${ }^{19}$. Staff innovative in this study refers to staff self-efficacy, knowledge sharing, and ideas generation. Innovation is an important part for the survival and the competency of an institution or organization.

Luszcyuska and Schwarzer ${ }^{20}$, they defined self-efficacy as a person's confidence and ability to execute an act required to produce effective result for the development of an organization. The term self-efficacy according to Bandura ${ }^{21}$ refers to a person's belief to

\footnotetext{
${ }^{15}$ Brown, M. E. \& Mitchell, M.S. Ethical and Unethical Leadership: Exploring New Avenue for Future Research. Business Ethics Quarterly, 20(4), (2010), 583-616.

${ }^{16}$ Carson, J. B., Tesluk, P. E. \& Marrone, J. A. Share Leadership in Teams: An Investigation of Antecedent Condition and Performance. Academy of Management Journal, 50, (2007), 1217-1234.

${ }^{17}$ Den Hartog, D. N., \& Den, H. Empowerment and Leader Fairness and Integrity: Studying Ethical Leader Behaviour from A Level of Analysis Perspective. European Journal of Work and Organizational Psychology, 18, (2009), 199-230.

${ }^{18}$ Martins, E. \& Treblanche, F. Building Organizational Culture that Stimulates Creativity and Innovation, European Journal of Innovation Management, 6(1), (2003), 67-74.

${ }^{19}$ Coakes, E. \& Smith, P. Develop Community's Innovation by Identifying Innovation Champions. International Journal of Knowledge and Organisation Learning Management, 14(1), (2007), 71-85.

${ }^{20}$ Luszcyuska, A. \& Schwarzer, R. Planning and Self-Efficacy in the Adoption and Maintenance of Breast Study Examination Longitudinal Study of Self-Regulatory. Journal of Cognition, Psychology and Health, 18, (2008), 93-108.

${ }^{21}$ Bandura, A. Self-efficacy: The Exercise of Control. (New York: Freeman, 1997).
} 
accomplish precise task positively. This means, a person's willingness to contribute immensely to complete a difficult task in order to attain predetermined goals. Generally, self-efficacy can be viewed as employees believe in the ability to perform task in an organization.

\section{Ethical leadership and staff innovative behaviour}

Workers are the crucial assets in an organization, the goal and objective can only be achieved through their efforts. Numerous studies have been conducted on ethical leaders on the achievement of staff innovative behaviour. The study of Toor and Ofori ${ }^{22}$ revealed that ethical leadership is likely to arouse the willingness of staff to put more effort in contributing their own quota to development of organization which will ultimately lead to increase in innovative behaviour. Leaders are expected to promote staff innovative behaviour by leading them towards change and transformation in order to realize organizational objectives ${ }^{23}$. Oates and Dalmau ${ }^{24}$ explains that ethical leadership is about doing something positive for the benefit of people in an organization in order to attain significant results.

\section{Theoretical Framework}

Theoretical framework used was based on path-goal theory posited by House and Mitchell ${ }^{25}$ as cited in Mulder ${ }^{26}$. According to Northhouse ${ }^{27}$; path-goal theory refers to a process in which the leaders choose specific behaviour that are best to the employee needs and organization. This theory holds that leader can facilitate innovative performance by showing staff members how their effort directly affects their receiving desired rewards. This theory stated that leadership behaviour is associated with four factors such as directive, supportive, participative, and achievement oriented. Following the path-goal theory, a leader may employ all four of the behaviours in different situations. The directive style is suitable for newly recruited staff ${ }^{28}$. Leana ${ }^{29}$ states that directive behaviour is positively related to subordinates innovative.

Supportive leaders create friendly environment and assist subordinates by showing interest in their performance when they show inability to complete a task ${ }^{30}$. Participative leaders seek suggestion from subordinates for making final decision by involving them in decision affecting the organization ${ }^{31 \& 32}$. The achievement-oriented leader establishes

${ }^{22}$ Toor, S. \& Ofori, G. Op.cit.

${ }^{23}$ Peter, O. O. Op.cit.

${ }^{24}$ Oates, V. \& Delmau, T. Op.cit.

${ }^{25}$ House, R. J. \& Mitchell, T. R. Path-Goal Theory of Leadership. Journal of Cotemporary Business, 5, (1974), 81-94.

${ }^{26}$ Mulder, P. Path-Goal Theory of Leadership. (2018). Retrieved (20/01/2019) from Tools Hero: https://www.tolshero.com/leaderhip/path-goal-theory-leadership.

${ }^{27}$ Northhouse, P. G. Leadership Theory and Practice. Thousand Oaks, (Sage Publications, Inc. 2013)

${ }^{28}$ Den Hartog, Op.cit.

${ }^{29}$ Leana, P. Path-Goal Theory, Leadership Style, Supervisor-Related Commitment And Gender. Emerging Leadership Journal, 6(1), (2013), 13-44.

${ }^{30}$ Mulder, P. Op.cit.

${ }^{31}$ Den Hartog, Op.cit.

${ }^{32}$ House, R. J. \& Mitchell, Op.cit. 
challenging goals and demonstrates confidence in subordinates in achieving these goals

${ }^{35}$. Theoretical framework of this study showed in figure 1 .

\section{Independent Variable}

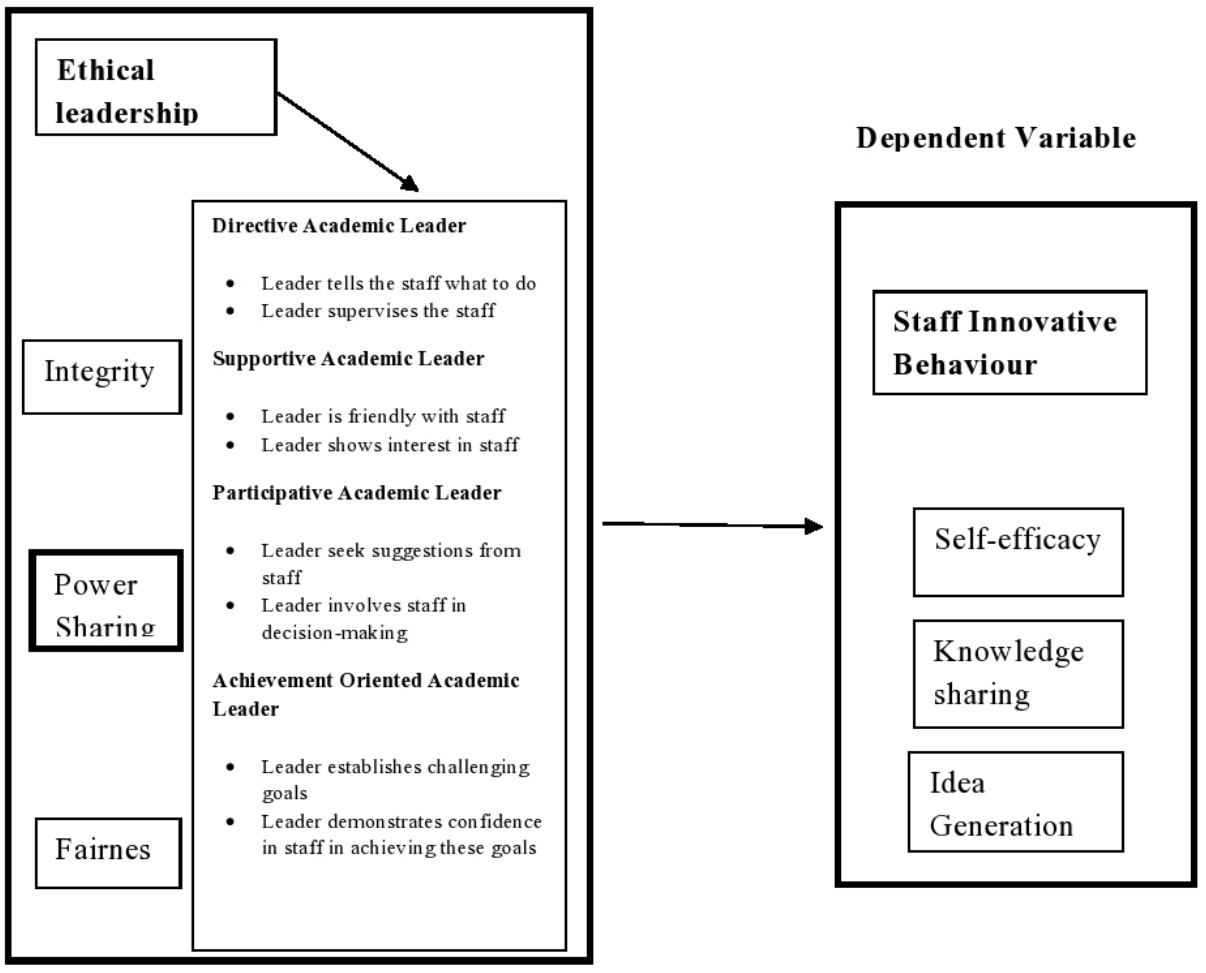

Figure 1: Theoretical Framework (adapted from Leana ${ }^{33}$ )

This theory can also be applied to the school system in that, a leader may employ directive behaviour when supervising a well-trained experience worker who is aware of the goal to be attained. Leader may also support the followers through power sharing and delegation of authority as well as involving them in decisions affecting the organization and respecting their views while making decision. Success oriented leaders can also establish stimulating goals to develop the followers and show faith in their capabilities to succeed.

This study anchored on this theory because it focuses on how leaders can bring about ethical and innovative behaviour in followers. The theory always reminds leaders that their specific function as a leader is to support the subordinates in defining their goals and also to help them in realizing those goals effectively. The path-goal theory provides

${ }^{33}$ Leana, P. Op.cit. 
the ground work of understanding by motivating staff to cultivate ethical behaviour in terms of self-efficacy, knowledge sharing and idea generation through coaching and direction of leader to achieve organizational goals and objectives.

\section{Research Method}

\section{Research design}

This study adopted qualitative research design. The design was considered suitable since it will enable researcher to determine the interaction that exist among leadership integrity, power sharing, fairness and staff innovative behaviour. Also, the chance to get view of the sample population, evaluate the data collected with the use of proper data analysis technique and reach a sensible decision about the population from the findings of the study ${ }^{34}$.

\section{Population and Sampling}

Population of this study comprised the administrative, teaching, and support staff in university of Ilorin, Kwara State, Nigeria. Target population consists of about 3500 staff. Out of this, the researcher decided to use a total of 350 participants based on recommendation of Research Advisor ${ }^{35}$. Sample table suggested that 346 participants are appropriate for this number. Therefore, the researcher increases the sample to 350 in order to avoid any doubt and also ensure quality of research findings. Stratified random sample process was used to select 350 participants in order to ensure that every participant of the population has equivalent right and opportunity of being carefully chosen. Thus, ensuring that all categories of staff in the university are represented in this study ${ }^{36}$.

\section{Instrument}

The research instrument for the present study comprised of constructed and adapted questionnaire from earlier studies by Ophillian ${ }^{37}$ on power sharing under ethical leadership. A total number of 25 items were used to measure ethical leadership with three subscales: integrity (10 items), power sharing (6 items), and fairness (9 items).

The items of questionnaire regarding staff innovative behaviour were concluded from Karani ${ }^{38}$ on self-efficacy and $\mathrm{Huda}^{39}$ on knowledge sharing. It consists of 20 items with

\footnotetext{
${ }^{34}$ Mayers, A. Introduction to Statistics and SPSS in Psychology ( $1{ }^{\text {st }}$ ed.) (England: Pearson Education Limited, 2013).

${ }^{35}$ Research Advisor (2006). Sample size table. http://www.research-advisor.com

${ }^{36}$ Creswell, J. W. Education Research: Planning, Conduction and Evaluating Quantitative and Qualitative Research (4 $4^{\text {th }}$ ed.). (Boston, MA: Pearson, 2012).

${ }^{37}$ Ophillian, L. Development and Validation of An Organizational Justice Measure Instrument for South African Context. Risk Governance and Control: Financial Market and Institution, 5(1), (2015), 27-38.

${ }^{38}$ Karani, N. N. Self-Efficacy Evaluation Survey on Chinese Employee: Case of Electronics Limited Company " $\mathrm{X}_{1}$ " (Shenzhen) and Investment Company Limited " $\mathrm{X}_{2}$ " (Beijing). International Journal of E-Education, E-Business, E-management and E-learning, 8(1), (2018). 51-57

${ }^{39}$ Huda, A. S. Determinants of Knowledge Sharing Behaviour Among Academics in United Arab Emirates. International Journal of Knowledge and Systems Science, 5(3), (2014), 54-70.
} 
three components; self-efficacy (9 items), knowledge sharing (6 items), and idea generation (5 items). Participants responded to five-point Likert scale: Strongly Agree $(\mathrm{SA})=5$, Agree $(\mathrm{A})=4$, Neutral $(\mathrm{N})=3$, Disagree $(\mathrm{D})=2$ and Strongly Disagree $(\mathrm{SD})$ $=1$.

\section{Reliability and Validity}

Reliability of the instrument was ensuring with the use of Cronbach's Alpha test. As shown in Table 1 and 2, the value for Cronbach's Alpha of this study was proven to be reliable and acceptable.

Table - 1

\section{Reliability test for Ethical Leadership}

\begin{tabular}{|l|l|c|l|}
\hline Variables & $\mathbf{N}$ & $\begin{array}{l}\text { Cronbach's } \\
\text { Alpha }\end{array}$ & Decision \\
\hline Integrity & 10 & 0.80 & All items are acceptable \\
\hline Power sharing & 6 & 0.84 & All items are acceptable \\
\hline Fairness & 9 & 0.86 & All items are acceptable \\
\hline
\end{tabular}

Table 1 shows that there are 10 items under integrity of ethical leadership. The value of the Cronbach's Alpha for the 10 items under integrity is 0.80 . It further reveals that there are 5 items under power sharing of ethical leadership with Cronbach's Alpha of 0.84. While fairness has 9 items with a Cronbach's Alpha of 0.86. According to Pallant ${ }^{40}$, values above .7 are considered acceptable and values above .8 are preferable and represent a good reliability. Therefore, the Cronbach's Alpha value for all the 3 dimensions of ethical leadership were around 0.80 . Therefore, the values show very good internal consistency reliability for scale and all the 25 items in the questionnaire are found to be reliable.

Table - 2

Reliability test for Staff innovative Behaviour

\begin{tabular}{|l|l|l|l|}
\hline Variables & N & $\begin{array}{l}\text { Cronbach's } \\
\text { Alpha }\end{array}$ & Decision \\
\hline Self-efficacy & 9 & 0.87 & All items are acceptable \\
\hline Knowledge sharing & 6 & 0.82 & All items are acceptable \\
\hline Idea generation & 5 & 0.86 & All items are acceptable \\
\hline
\end{tabular}

${ }^{40}$ Pallant, J. A step by step guide to data analysis using SPSS: Survival manual. (4 $4^{\text {th }}$ ed.), (Australia: Allen and Unwin, 2011). 
Table 2 shows the 3 main dimensions of staff innovative behaviour. These are selfefficacy, knowledge sharing and idea generation to measure staff innovative behaviour. The Cronbach's Alpha value for self-efficacy is 0.87 covering up to 9 number of items. In addition, 6 items from knowledge sharing of staff innovative behaviour has Cronbach's Alpha value of 0.82 and 0.86 for idea generation. In summary, all instrument items for staff innovative behaviour used are reliable and acceptable for this study.

\section{Process of Data Collection}

Researcher with the aid of three research assistants distributed the questionnaire to the participants. The questionnaire was distributed to over 400 participants consisting of selected administrative, teaching and support staff in the university of Ilorin, Kwara State, Nigeria. These participants were contacted in their respective offices to discuss the basis of the study before the distribution of the questionnaire. After 2 weeks, all the answered questionnaires were collected from the participants. However, a total of 350 questionnaires were returned and filled properly. Therefore, the returned number meet the suggestion of Research Advisor ${ }^{41}$ with a number of 350 participants sample in this study.

\section{Analysis of Collected Data}

The data collected for this study was then key-in the SPSS and analyzed using descriptive statistics like simple percentage for demographic information and inferential statistic was used in order to explain the relationship between both variables. It also meant to identify the overall impact of the ethical leadership variables on staff innovative behaviour.

\section{Findings}

\section{Demographic Profile of Participants}

This section presents a comprehensive result of the analysis made from the data collected in this study. It stated with an analysis of the demographic information of participants who participated using descriptive statistics

\footnotetext{
${ }^{41}$ Research Advisor (2006). Op.cit.
} 
Table - 3

Demographic Profile of the Participants

\begin{tabular}{l|l|l|l}
\hline & & $\mathrm{N}=350$ & Percentage (\%) \\
\hline Gender: & Female & 118 & $33.7 \%$ \\
& Male & 232 & $66.3 \%$ \\
\hline & & 350 & $100 \%$ \\
\hline Age: & $21-30$ & 100 & 28.6 \\
& $31-40$ & 134 & $38.3 \%$ \\
& $41-50$ & 96 & $27.4 \%$ \\
& 51 above & 20 & $5.7 \%$ \\
\hline & & 350 & $100 \%$ \\
\hline Qualification & HND & 45 & $12.9 \%$ \\
& Bachelor degree & 70 & $20 \%$ \\
& Master degree & 90 & $25.7 \%$ \\
& Ph.D. & 145 & $41.4 \%$ \\
\hline Year of experience & & 350 & $100 \%$ \\
& $1-4$ years & 40 & $11.4 \%$ \\
& $5-9$ years & 90 & $25.7 \%$ \\
& $10-14$ years & 104 & $29.7 \%$ \\
& $15-19$ years & 96 & $27.4 \%$ \\
& 20 years above & 20 & $5.7 \%$ \\
\hline & & 350 & $100 \%$ \\
\hline
\end{tabular}

Table 3 shows the demographic information of participants that participated in this study. From the table 118 participants (33.7\%) are female and 232 participants are male $(66.3 \%)$. In terms of average age of the participants, table 3 presented that $100(28.6 \%)$ are participants between the age of 21-30, majority 134 of the participants $(38.3 \%)$ are between age 31-40 years, and $96(27.4 \%)$ of the participants are between age 41-50 years as well as 20 of the participants $(5.7 \%)$ are over 50 years.

Based on qualification of the participants, 45 participants (12.9\%) are Higher National Diploma holders, 70 participants (20\%) are bachelor degree holders while 90 participants (25.7\%) are master degree holders, majority of the participants $145(41.4 \%)$ are $\mathrm{Ph} . \mathrm{D}$ holders. In the aspect of year of experience, 40 participants (11.4\%) have 1-5 years of experience, and 90 participants $(25.7 \%)$ have 6-10 years of experience, majority 104 participants (29.7\%) have 11-15 years of experience, there are 96 participants (27.4\%) who have $15-19$ years of experience while 20 participants (5.7\%) have 20 years and above experience in the sample university. 


\section{Level of Ethical Leadership}

Objective 1: determine the level of ethical leadership practice as perceived by staff in university of Ilorin, Nigeria.

Table 4 presents the mean and standard deviation for each measurement of ethical leadership and overall result for level of ethical leadership practice.

Table - 4

\section{Level of Ethical Leadership Practice}

\begin{tabular}{|l|c|c|c|}
\hline \multicolumn{1}{|c|}{ Variables } & Mean & $\begin{array}{c}\text { Standard } \\
\text { Deviation }\end{array}$ & Level \\
\hline Measurement of Integrity & 2.93 & 0.966 & Moderate \\
\hline Measurement of Power Sharing & 2.95 & 0.968 & Moderate \\
\hline Measurement of Fairness & 2.92 & 0.966 & Moderate \\
\hline $\begin{array}{l}\text { Overall Level of Ethical } \\
\text { Leadership Practice }\end{array}$ & 2.93 & 0,967 & Moderate \\
\hline
\end{tabular}

Table 4 shows the overall level of ethical leadership practice is moderate with mean value of 2.93 and standard deviation of 0.967 . This indicated that most of the staff perceives their leaders as giving them a moderate level of ethical behaviour in terms of integrity, power sharing and fairness.

Level of Staff Innovative Behaviour

\section{Objective 2: To measure the level of staff innovative behaviour in university of} Ilorin, Nigeria.

This section explains the mean and standard deviation value that show the level of staff innovative behaviour.

Table - 5

Level of Staff Innovative Behaviour

\begin{tabular}{|l|c|c|c|}
\hline \multicolumn{1}{|c|}{ Variables } & Mean & Standard Deviation & Level \\
\hline Measurement of Self-efficacy & 2.89 & 0.977 & Moderate \\
\hline $\begin{array}{l}\text { Measurement of Knowledge } \\
\text { sharing }\end{array}$ & 2.91 & 0.974 & Moderate \\
\hline $\begin{array}{l}\text { Measurement of Idea } \\
\text { Generation }\end{array}$ & 2.90 & 0.969 & Moderate \\
\hline $\begin{array}{l}\text { Overall Level of Staff } \\
\text { Innovative Behaviour }\end{array}$ & 2.90 & 0.973 & Moderate \\
\hline
\end{tabular}

The analysis presented in table 5 presents the means and standard deviations for all measurements of staff innovative behaviour such as self-efficacy, knowledge sharing and idea generation. The overall result of staff innovative behaviour is at moderate level (Mean $=2.90, \mathrm{SD}=0.973)$. Furthermore, among three measurements of staff innovative 
behaviour, the findings showed that participants have a low mean in term of selfefficacy (Mean $=2.89, \mathrm{SD}=0.977$ ). From the finding, it shows that staff- efficacy needs to be improved in order to enhance their innovative behaviour.

\section{Hypotheses Testing}

$\mathrm{Ho}_{1:}$ There is no significant relationship between integrity and staff innovative behaviour.

$\mathrm{Ho}_{2}$ : There is no significant relationship between power sharing and staff innovative behaviour.

$\mathrm{Ho}_{3}$ : There is no significant relationship between fairness and staff innovative behaviour

Pearson product moment correlation statistic was used to analyze the relationship between ethical leadership variables and staff innovative behaviour.

$\mathrm{Ho}_{1}$ : There is no significant relationship between integrity and staff innovative behaviour.

Table - 6

Correlational Analysis for Integrity and Staff Innovative Behaviour

\begin{tabular}{|l|l|l|l|}
\hline & & Integrity & $\begin{array}{l}\text { Staff Innovative } \\
\text { Behavior }\end{array}$ \\
\hline Integrity & Pearson correlation & 1 & $.924^{* *}$ \\
\hline & $\begin{array}{l}\text { Sig. } \\
(2 \text {-taled })\end{array}$ & & .000 \\
\hline & $\mathrm{N}$ & 350 & 350 \\
\hline $\begin{array}{l}\text { Staff Innovative } \\
\text { Behaviour }\end{array}$ & Pearson correlation & $.924^{* *}$ & 1 \\
\hline & $\begin{array}{l}\text { Sig. } \\
(2 \text {-tailed })\end{array}$ & .000 & \\
\hline & $\mathrm{N}$ & 350 & 350 \\
\hline
\end{tabular}

Table 6 indicates that leader's integrity has a significant and positive relationship with staff innovative behaviour with calculated $\mathrm{r}$-value $=.924 ; \mathrm{p}<.000$. This displays that there is a significant and positive relationship between integrity and staff innovative behaviour in university. Therefore, the hypothesis which states that there is no significant relationship between integrity and staff innovative behaviour is rejected.

$\mathrm{Ho}_{2}$ : There is no significant relationship between power sharing and staff innovative behaviour 
Table - 7

Correlational Analysis for power sharing and Staff Innovative Behaviour

\begin{tabular}{|l|l|l|l|}
\hline & & Power Sharing & $\begin{array}{l}\text { Staff Innovative } \\
\text { Behavior }\end{array}$ \\
\hline Power Sharing & Pearson correlation & 1 & $.915^{* *}$ \\
\hline & $\begin{array}{l}\text { Sig. } \\
(2 \text {-tailed })\end{array}$ & & .000 \\
\hline & N & 350 & 350 \\
\hline $\begin{array}{l}\text { Staff Innovative } \\
\text { Behaviour }\end{array}$ & Pearson correlation & $.915^{* *}$ & 1 \\
\hline & $\begin{array}{l}\text { Sig. } \\
(2 \text {-tailed })\end{array}$ & .000 & \\
\hline & N & 350 & 350 \\
\hline
\end{tabular}

Table 7 indicates that power sharing has a positive and perfect relationship with staff innovative behaviour with calculated $r$-value $=.915 ; \mathrm{p}<.000$. This shows that there is a positive and significant relationship between power sharing and staff innovative behaviour in the university. Therefore, the hypothesis which state that there is no significant relationship between power sharing and staff innovative behaviour is rejected.

$\mathrm{Ho}_{3}$ : There is no significant relationship between fairness and staff innovative behaviour

Table - 8

Correlational Analysis for Fairness and Staff Innovative Behaviour

\begin{tabular}{|l|l|l|l|}
\hline & & Fairness & $\begin{array}{l}\text { Staff Innovative } \\
\text { Behavior }\end{array}$ \\
\hline Fairness & Pearson correlation & 1 & $.915^{* *}$ \\
\hline & $\begin{array}{l}\text { Sig. } \\
(2 \text {-tailed })\end{array}$ & & .000 \\
\hline $\begin{array}{l}\text { Staff Innovative } \\
\text { Behaviour }\end{array}$ & $\mathrm{N}$ & 350 & 350 \\
\hline & Pearson correlation & $.915^{* *}$ & 1 \\
\hline & $\begin{array}{l}\text { Sig. } \\
(2 \text {-tailed })\end{array}$ & .000 & 350 \\
\hline
\end{tabular}

Table 8 indicates that fairness of leader has a significant and positive relationship with staff innovative behaviour with calculated $\mathrm{r}$-value $=.915 ; \mathrm{p}<.000$. This reveals that there is a significant and perfect relationship between fairness and staff innovative 
behaviour in university. Therefore, the hypothesis which states that there is no significant relationship between fairness and staff innovative behaviour is rejected.

\section{Linear Regression Analysis}

Objective 3: To identify the effect of ethical leadership practice on staff innovative behaviour in university of Ilorin, Nigeria.

This explains the linear regression finding that measure the effect of ethical leadership practice on staff innovative behaviour in university of Ilorin, Nigeria.

Table - 9

Linear Regression of Ethical Leadership and Staff Innovative Behaviour

\begin{tabular}{|l|l|l|l|l|l|}
\hline Model & R & R Square & $\begin{array}{l}\text { Adjusted } \\
\text { Square }\end{array}$ & $\begin{array}{l}\text { Std. Error of the } \\
\text { Estimate }\end{array}$ \\
\hline 1 & .918 & .854 & .853 & .995 & \\
\hline
\end{tabular}

a. Predictor: (Constant) Ethical Leadership

Table 9 shows that ethical leadership practice has effect on staff innovative behaviour with 85.4 by staff regarding of $\mathrm{R}$ square value from the table. Therefore, the result showed that ethical leadership practice by academic leaders could have impact on staff innovative behaviour.

Table - 10

Linear Regression coefficients for Ethical Leadership and Staff Innovative Behaviour

\begin{tabular}{|c|l|c|c|c|c|c|}
\hline Model & & $\begin{array}{c}\text { Unstandardized } \\
\text { Coefficients }\end{array}$ & & $\begin{array}{c}\text { Standardized } \\
\text { Coefficients }\end{array}$ & T & Sig. \\
\hline & $\mathbf{B}$ & $\begin{array}{c}\text { Std } \\
\text { Error }\end{array}$ & Beta & & \\
\hline & (Constant) & .451 & .221 & & 5.985 & .000 \\
\hline & $\begin{array}{l}\text { Ethical } \\
\text { Leadership }\end{array}$ & .601 & .010 & .504 & 5.071 & .000 \\
\hline
\end{tabular}

a. Dependent Variable: Staff Innovative Behaviour

According to Table 10, the standard regression weight of the beta coefficient value for ethical leadership was 0.504 which indicated that the increase in ethical leadership practice by academic leaders responsible for increase in staff innovative behaviour. The table also shows that the ethical leadership and staff innovative behaviour were positively related. T-test of 5.5071 was sufficiently high with corresponding p-value of 
0.000. Therefore, there is significant and positive relationship between ethical leadership and staff innovative behaviour.

\section{Discussion and Recommendations}

The findings of this study emphasized the moderate level for integrity, power sharing and fairness, based on the staff perception. The aim of higher education system is to develop the intellectual capacity of individuals through appropriate manpower training. Therefore, it is the responsibility of educational administrators to demonstrate effective ethical leadership practices that will lead to better staff innovative behaviour.

From the first research hypothesis, it was found that leadership integrity has positive and significant impact on staff innovative behaviour. This implies that whenever academic leaders demonstrate high standards of professional conduct, encourage an open and transparent culture, adhere to laws and rules as well as act honourably in an organization, there is inclination that their subordinates will develop innovatively. This shows that leadership play a crucial role in enhancing staff innovative behaviour. This finding agreed with finding of Agha et.al. ${ }^{42}$ that leaders' integrity has a significant and positive impact on endurance commitment of staff in an organization.

This finding is also germane to that of Collins ${ }^{43}$ who stated that employees always feel happy to associate with leaders that possess credible integrity. Furthermore, leadership power sharing has a perfect and substantial relationship with staff innovative behaviour. Table 7 indicated that leadership power sharing is positively related and significantly influence the staff innovative behaviour. The result concurs with the findings from Carson et.al ${ }^{44}$ who reported that knowledge sharing is the key aspect of power sharing that can bring about enhancement of staff innovative behaviour. Thus, ethical leadership is positively related to staff innovative behaviour through power sharing that will lead to self-efficacy ${ }^{45}$.

Fidan and Ozturk ${ }^{46}$ conclude that fairness and well treatment encourage staff to develop new ideas which in turn lead to innovation in an organization. The results from hypothesis three indicated that leadership fairness has significant influence on staff innovative behaviour.

This implies that fairness of leaders in terms of promoting staff base on their skill and publications, having equal access to institution resources, unbiased evaluation of their performance and the likes bring about effective staff innovative behaviour. The findings

${ }^{42}$ Agha, N. C., Op.cit.

${ }^{43}$ Collins, D. Designing Ethical Organisation for Spiritual Growth and Superior Performance: An Organisation System Approach. Journal of Management, Spirituality, and Religion, 7(2), (2010), 95-117.

${ }^{44}$ Carson, J. B., Op.cit.

${ }^{45}$ May C. W., Ribbens, B. \& Zhou, J. Linking Ethical Leadership to Employee Creativity: Knowledge Sharing and Self-Efficacy Mediators. International Journal of Social Behaviour and Personality, 41, (2013), 409420.

${ }^{46}$ Fidan, T. \& Ozturk, I. Relationship of Creativity of Public and Private School Teachers to their Intrinsic Motivation. Procedia-Social and Behavioural Science, 195, (2015), 905-914. Doi:10.1016/jsbspro.2015.06.370. 
of this study were consistent with previous research ${ }^{47}$ which concluded that fairness have significant influence in defining the perception of ethical leadership.

The linear regression analysis conducted to find the extent of ethical leadership effect on the staff innovative behaviour in Nigeria. The finding shows that there is a solid and significant relationship between ethical leadership measurements and staff innovative behaviour in Nigeria. This is an indication that improvement of the measurements (integrity, power sharing, and fairness) of ethical leadership practice in the management of the university has a strong chance of enhancing effective staff innovative behaviour. The findings of this study agreed with Brown and Trevino ${ }^{48}$ that leader gifted with ethical perception improve their subordinates innovative behaviour. Also, germane to Ibara and Hansen ${ }^{49}$ that ethical leadership encourages employees to contribute positively to the development of organization.

The study co-aligns with the finding of Mumford ${ }^{50}$ that leader's behaviour undeniably shapes the innovative ability of organizational staff. In addition, Heba ${ }^{51}$ has asserted that ethical leadership dimensions have an helpful effect on staff innovative. The finding is in line with the position of Peter ${ }^{52}$ who asserted that strong and positive leader display high quality in an organisation. Furthermore, this finding conformed to Grace $^{54}$ who stated that ethical leadership plays a positive role in managing educational organisation in line with ethical principles and actions.

Based on this finding, it has been recommended that academic leaders should continue to demonstrate high standards of professional conduct; adhering to laws, rules and ethical standards; passionate about their work; encourage an open and transparent culture; and acting honourably in order to drive and stimulate staff innovative behavior. Furthermore, in order to ensure effective power sharing, academic leaders should develop a framework that will encourage staff to be able to work together irrespective of their race, gender, religion or age; consulting staff before changes are implemented; and constantly interact with all the staff in the organization.

Also, academic leaders should continue to demonstrate effective fairness in terms of unbiased evaluation of staff performance; promotion of staff based on their skills and publications; supports fair practices in the departments or units unconditionally; as well as ensuring fair distribution of financial resources to different departments or units in an organization. This shows that staff innovative behaviour (self-efficacy, knowledge sharing, and idea generation) will be improved when leaders are able to act morally towards the improvement of university education.

\footnotetext{
${ }^{47}$ Anderson, C., Spataro, S. E., \& Flynn, F.J. Personality and Organizational Culture as Determinant of Influence. Journal of Applied Psychology, 93, (2008), 702-710.

${ }^{48}$ Brown, M. E., Trevino, L. K. \& Harrison, D. Ethical Leadership., Op.cit.

${ }^{49}$ Ibara, H. \& Hansen, M. Are You a Collaborative Leader? Harvard Business Review, 89(7/8), (2011), 68-74.

${ }^{50}$ Mumford, M. D. Where Have We Been, Where Are We Going? Taking Stock in Creative Research. Creative Research Journal, 15, (2003), 107-120.

${ }^{51}$ Heba, K. E. Op.cit.

${ }^{52}$ Peter, O. O. Op.cit.
} 


\section{Implications and Conclusion}

The findings of this study will be of great advantage to academic leaders, staff and stakeholders in education. The practical implication of this study revealed ethical leadership indices that influence staff innovative behaviour. Having known the dependable indicators, academic leaders are able to provide ethical leadership to enhance and improve staff innovative behaviour. Based on the findings, it was revealed that ethical leadership significantly influences the staff innovative behaviour. This may help the academic leaders and stakeholders to revise their behaviour as they could be aware on which of the measurements from ethical leadership are appropriate in dealing with staff in order to develop staff innovative behaviour. In addition, this study would encourage both lecturers and technical staff to understand their roles in supporting academic leaders in discharging appropriate ethics behaviour in order to enhance effective innovation.

Staff innovative behaviour could be realized through effective leaders' integrity, power sharing and fairness. Ethical leadership is a sure way to prepare staff towards selfefficacy, knowledge sharing, and idea generation in order to render quality service to university education.

\section{Bibliography}

Adeyemi, T. O. Human resources in education. J. B Babalola \& A. O. Ayeni (Eds.), Educational management theories and tasks. (Lagos: Macmillan Publishers Limited, 2009).

Agha, N. C., Nwekpa, K. C. \& Eze, O. R. Impact of Ethical Leadership on Employee Commitment in Nigeria: A Study of Innoson Technical and Industrial Company Limited, Enugu. International Journal of Development and management, 12(1), (2017).

Anderson, C., Spataro, S. E., \& Flynn, F.J. Personality and Organizational Culture as Determinant of Influence. Journal of Applied Psychology, 93, (2008).

Bandura, A. Self-efficacy: The Exercise of Control. (New York: Freeman, 1997).

Brown, M. E. \& Mitchell, M.S. Ethical and Unethical Leadership: Exploring New Avenue for Future Research. Business Ethics Quarterly, 20(4), (2010).

Brown, M. E., Trevino, L. K. \& Harrison, D. Ethical Leadership: A Social Learning Perspective for Construct Development and Testing. Journal of Organisational Behaviour and Human Decision Process, 97, (2005).

Carson, J. B., Tesluk, P. E. \& Marrone, J. A. Share Leadership in Teams: An Investigation of Antecedent Condition and Performance. Academy of Management Journal, 50, (2007).

Ciulla, J. B. Ethics: The Heart Of Leadership. (2 $2^{\text {nd }}$ ed.), (USA: Quorum Books, 2014)

Coakes, E. \& Smith, P. Develop Community's Innovation by Identifying Innovation Champions. International Journal of Knowledge and Organisation Learning Management, 14(1), (2007).

Collins, D. Designing Ethical Organisation for Spiritual Growth and Superior Performance: An Organisation System Approach. Journal of Management, Spirituality, and Religion, 7(2), (2010). 
Creswell, J. W. Education Research: Planning, Conduction and Evaluating Quantitative and Qualitative Research (4 ${ }^{\text {th }}$ ed.). (Boston, MA: Pearson, 2012).

Den Hartog, D. N., \& Den, H. Empowerment and Leader Fairness And Integrity: Studying Ethical Leader Behaviour from A Level of Analysis Perspective. European Journal of Work and Organizational Psychology, 18, (2009).

Fidan, T. \& Ozturk, I. Relationship of Creativity of Public and Private School Teachers to their Intrinsic Motivation. Procedia-Social and Behavioural Science, 195, (2015), 905-914. Doi:10.1016/jsbspro.2015.06.370.

Heba, K. E. Influence of Ethical Leadership on Workers Creativity. International Journal of Economics and management Sciences, 7(5), (2018).

House, R. J. \& Mitchell, T. R. Path-Goal Theory of Leadership. Journal of Cotemporary Business, 5, (1974).

Huda, A. S. Determinants of Knowledge Sharing Behaviour Among Academics in United Arab Emirates. International Journal of Knowledge and Systems Science, 5(3), (2014).

Ibara, H. \& Hansen, M. Are You a Collaborative Leader? Harvard Business Review, 89(7/8), (2011).

Karani, N. N. Self-Efficacy Evaluation Survey on Chinese Employee: Case of Electronics Limited Company " $\mathrm{X}_{1}$ " (Shenzhen) and Investment Company Limited " $\mathrm{X}_{2}$ " (Beijing). International Journal of E-Education, EBusiness, E-management and E-learning, 8(1), (2018).

Khan, M. F. U. Role of Performance Appraisal System on Employee Motivation. Journal of Business Management, 8(1), (2011).

Leana, P. Path-Goal Theory, Leadership Style, Supervisor-Related Commitment And Gender. Emerging Leadership Journal, 6(1), (2013).

Luszcyuska, A. \& Schwarzer, R. Planning and Self-Efficacy in the Adoption and Maintenance of Breast Study Examination Longitudinal Study of Self-Regulatory. Journal of Cognition, Psychology and Health, 18, (2008).

Martins, E. \& Treblanche, F. Building Organizational Culture that Stimulates Creativity and Innovation, European Journal of Innovation Management, 6(1), (2003).

May C. W., Ribbens, B. \& Zhou, J. Linking Ethical Leadership to Employee Creativity: Knowledge Sharing and Self-Efficacy Mediators. International Journal of Social Behaviour and Personality, 41, (2013).

Mayers, A. Introduction to Statistics and SPSS in Psychology ( $1^{\text {st }}$ ed.) (England: Pearson Education Limited, 2013).

Mulder, P. Path-Goal Theory of Leadership. (2018), Retrieved (20/01/2019) from ToolsHero:

https://www.tolshero.com/leaderhip/path-goal-theory-leadership.

Mumford, M. D. Where Have We Been, Where Are We Going? Taking Stock in Creative Research. Creative Research Journal, 15, (2003).

Northhouse, P. G. Leadership Theory and Practice. Thousand Oaks, (CA: Sage, 2010)

Northhouse, P. G. Leadership Theory and Practice. Thousand Oaks, (Sage Publications, Inc. 2013)

Oates, V. \& Delmau, T. Ethical Leadership: A Legacy for Longer Future. Journal of Performance, 5(2), (2013). 
Onyeizugbe, C. U., Obiageli, L. O. \& Igbodo, R. O. Tertiary Education Trust Fund International Programmes and Academic Staff Development of Selected Universities in South East, Nigeria. Journal of Economics and Public Finance, 2(1), (2016.

Ophillian, L. Development and Validation of An Organizational Justice Measure Instrument for South African Context. Risk Governance and Control: Financial Market and Institution, 5(1), (2015).

Pallant, J. A step by step guide to data analysis using SPSS: Survival manual. ( ${ }^{\text {th }}$ ed.), (Australia: Allen and Unwin, 2011).

Peter, O. O. Ethical Leadership on Employee Performance in Uganda. Net Journal of Business Management, 3(1), (2015).

Research Advisor (2006). Sample size table. http://www.research-advisor.com

Shamia, D. R. \& Andi, I. Y. Influence of Ethical Leadership on Employee Well-Being: The Mediating Role of Psychological Empowerment. Journal of Indonesian Economy and Business, 32(2), (2017).

Taqveen, T. Z. \& Ajimal, W. Influence of Ethical Leadership on Innovative Work Behaviour: Examination of Individual Level of Psychological Mediators. Pakistan Journal of Commerce and Social Sciences, 11(2), (2017).

Toor, S. \& Ofori, G. Ethical Leadership: Examining the Relationship with Full Range Leadership Model, Employee Outcome and Organizational Culture. Journal of Business Ethics, 90, (2009).

Zhu., W., May, D. R. \& Avolio, B J. The Impact of Ethical Leadership Behaviour on Employee Outcome: The Role of Psychological Empowerment and Authenticity. Journal of Leadership and Organizational Studies, 11, (2004). 